(C) М.О. Артеменко, О.Ю. Усенко, 2018

УДК 616.14-002.2

\title{
Рецидиви варикозної хвороби після застосування ендовазальних термічних методик
}

\author{
М.О. Артеменко, О.Ю. Усенко \\ ukr.phlebolog@gmail.com \\ Наџіональний інститут хірургї та трансплантології імені О.О. Шалімова НАМН Украӥни, Київ
}

\section{Реферат}

Вступ. За останнє десятиріччя мініінвазивні методики фактично замінили «класичну» хірургію варикозної хвороби в світі та активно витісняють ії в Україні. Але радикально знизити ризик рецидивів порівняно з «класичною» хірургією поки не вдається, до того ж застосування цих методик для лікування рецидивних форм варикозної хвороби (РФВХ) є неабияким викликом навіть для досвідченого флеболога.

Мета дослідження. Оцінити частоту РФВХ після застосування ендовазальних термічних (ЕТ) методик та показати результати застосування ЕТ методик в лікуванні РФВХ.

Матеріали та методи. Нерандомізоване ретроспективне дослідження за період з листопада 2015 року по квітень 2018 року включало 420 пацієнтів, яким були проведені ЕТ методики, що включали 86 (20,48\%) пацієнтів з РФВХ, 3 них 19 (4,52\%) пацієнтів з РФВХ після лікування на власній базі. Пацієнтам з РФВХ проводились ЕВЛК та пінна склеротерапія (ПС). 38 (44,19\%) пацієнтам була проведена ЕВЛК, 28 (32,56\%) пацієнтам - ПС, 20 (23,25\%) пацієнтам була проведена ЕВЛК в поєднанні з ПС.

Результати досліджень та їх обговорення. Через 3, 6 та 12 місяців у 81 (94,19\%) пацієнта оброблені вени були оклюзовані, у $5(5,81 \%)$ пацієнтів був виявлений новий рефлюкс на пролікованих кінцівках. При цьому якість життя поліпшилась в усіх випадках - середня кількість балів VCSS до лікування складала 5,2, через 1 місяць VCSS складав 1,9; через 6 та 12 місяців кількість балів VCSS складала 1,3.

Висновки. Повторне застосування мінінвазивних методик у пацієнтів з РФВХ $є$ технічно непростим завданням, але має ефективність на рівні 94\%. Частота рецидивів після ЕТ методик відповідає загальносвітовим даним.

Ключові слова: ендовазальна лазерна коагуляція, радіочастотна облітерація, рецидив, варикозна хвороба, пінна склеротерапія

The problem of recurrence of varicose disease in the perspective of the use of endovascular thermal techniques: an analysis of own experience

Artemenko M.O., Usenko O.Yu.

National Institute for Surgery and Transplantology named after O.O. Shalimov, National Academy of Medical Science of Ukraine, Kyiv

Abstract
Over the last decade, minimally invasive techniques have in fact replaced the "classic" surgery of varicose veins in the world and actively supplant it in Ukraine. But it is still not possible to radically reduce the risk of recurrence in comparison with "classical" surgery, besides the application of these methods for the treatment of recurrent forms of varicose veins (RFVV) is a significant challenge, even for an experienced phlebologist.

The aim of the study was to evaluate the frequency of RFVV after application of endovascular thermal (ET) techniques and to show the results of the use of ET techniques in the treatment of RFVV.

Materials and methods. The unannounced retrospective study for the period from November 2015 to April 2018 included 420 patients undergoing ET techniques, which included 86 (20.48\%) patients with RFVV, of which $19(4.52 \%)$ of patients with RFVV after treatment at your own base. Patients with RFVV underwent endovasal laser treatment (EVLT) and lor ultrasound-controlled foam sclerotherapy (UFS). 38 (44,19\%) patients had EVLT, 28 (32.56\%) patients UFS, 20 (23.25\%) patients had EVLT in combination with UFS. After 3, 6 and 12 months, in 81 (94.19\%) cases occlusion of the treated vein was observed, and in $5(5.81 \%)$ cases a new reflux on the treated limb emerged. In all cases, the quality of life improved - the average number of VCSS points was: before treatment 5.2, in 1 month after - VCSS was 1.9; in 6 and 12 months, the number of VCSS points was 1.3 .

Conclusion. Repeated use of minimally invasive techniques in patients with RFVV is a technically challenging task, but has a high efficiency of $94 \%$. Relapse rate after ET techniques corresponds to world-wide data.

Вступ. За останні роки ендовазальні термічні методики (ЕТ) витіснили «класичну» хірургію варикозної хвороби в світі. Вражаючі результати застосування ендовазальної лазерної коагуляції (ЕВЛК) та радіочастотної облітерації (РЧО) вен призвели до того, що за якісь десять років дані методики стали переважати в хірургічному лікуванні варикозної хвороби (BX) [1]. Відмінні короткострокові результати подарували надію сучасним флебологам та їх пацієнтам. Але вже дані се- редньо- та довгострокових результатів, на жаль, показують рівень рецидивів ВХ не кращі за «класичний» стрипінг [2]. ЕТ методики розвиваються та вдосконалюються 3 плином часу, покращуються результати, але значно знизити частоту рецидивів поки не вдається. Більше того, застосування саме сучасних методик для лікування рецидивних форм варикозної хвороби (РФВХ) є досить складним завданням навіть для досвідченого флеболога. 
Мета дослідження. Метою дослідження було оцінити частоту виникнення РФВХ після застосування ЕТ методик та спробувати визначити можливі причини їх виникнення.

Матеріали та методи. Нерандомізоване ретроспективне дослідження за період з листопада 2015 року по квітень 2018 року включало 420 пацієнтів, яким було проведені ЕТ методики на базі кабінету лазерної хірургії НIXТ ім. О.О. Шалімова. Було відібрано 86 (20,48\%) пацієнтів з РФВХ, із них 19 (4,52\%) пацієнтів з РФВХ після проходження лікування на власній базі. Остання категорія пацієнтів була визначена як «повторні», інші 67 (15,96\%) пацієнтів з РФВХ - як «первинні».

Таблиця 1

Зведені статистичні дані по пацієнтах

\begin{tabular}{|l|c|c|c|}
\hline \multicolumn{1}{|c|}{ Показник } & $\begin{array}{c}\text { Паціснти } \\
\text { загалом }\end{array}$ & $\begin{array}{c}\text { Паціснти 3 } \\
\text { РФВХ }\end{array}$ & Критерій Р \\
\hline Стать (Ч/Ж) & $130 / 204$ & $34 / 52$ & 0,883 \\
\hline Середній вік (роки) & $49,71 \pm 5,39$ & $54,21 \pm 6,21$ & 0,106 \\
\hline Передопераційний VCSS & $8,1 \pm 6,2$ & $8,7 \pm 7,3$ & 0,346 \\
\hline Уражений венозний басейн (ВПВ/MПВ/інші) & $246 / 56 / 32$ & $37 / 31 / 18$ & 0,286 \\
\hline Різновид операції (ЕВЛК/РЧО) & $320 / 14$ & $81 / 5$ & 0,976 \\
\hline Кількість часу з моменту операції (місяці) & - & $19,32 \pm 5,86$ & - \\
\hline \multicolumn{2}{|c|}{ СЕАР по класах: } \\
\hline С2 & 231 & 15 & - \\
\hline С3 & 48 & 53 & - \\
\hline С4 & 36 & 13 & - \\
\hline С5/6 & 5 & - \\
\hline
\end{tabular}

Оцінюючи статистичні дані, варто звернути увагу на декілька важливих моментів. Достовірної різниці в статевому та віковому розподілі виявлено не було, різниця в якості життя, оцінена за VCSS, також була недостовірною. В клініці (з немедичних причин), в основному проводилась ЕВЛК, кількість РЧО була незначною, порівняно з ЕВЛК. У випадку РФВХ, якщо пацієнту проводилось декілька операцій, час до виникнення рецидиву відраховувався від найпершої.

Дані розподілу по класах СЕАР може свідчити як про те, що важкі форми ВX (С3-6) більш схильні до рецидиву, ніж С2; так і про те, що пацієнти 3

більш важкими формами ВX, що виникли на фоні РФВХ більш схильні до повторного звернення за медичною допомогою i, відповідно, хірургічної корекції.

3 метою аналізу можливих причин та механізмів розвитку рецидиву, всі пацієнти з РФВХ були поділені на 3 умовні категорії:

1) $з$ реканалізацією раніше пролікованого стовбура;

2) 3 неоангіогенезом зони співусть або сафенного простору;

3) 3 розвитком рефлюксу в інших зонах або венозних басейнах, що не були проліковані раніше.

Таблиця 2

Розподіл пацієнтів із РФВХ по категоріях

\begin{tabular}{|l|c|c|c|}
\hline & 1 категорія & 2 категорія & 3 категорія \\
\hline Група «первинних» & $11(16,42 \%)$ & $32(47,76 \%)$ & $24(35,82 \%)$ \\
\hline Група «повторних» & $2(10,52 \%)$ & $1(5,26 \%)$ & $16(84,22 \%)$ \\
\hline
\end{tabular}

1 категорія пацієнтів розглядалася як «чистий» рецидив після лікування, найбільш частими та вірогідними причинами якого були технічні чи тактичні помилки під час первинного лікування. Також, 3 власного досвіду, реканалізація стовбура вени могла виникати, якщо даний стовбур містив тромботичні маси (навіть залишкові) в просвіті вени під час коагуляції. Поява неоангіогенезу ділянки співусть або сафенного простору, характерна для 2 категорії пацієнтів, у літературі пояснюється контактом інтими 3 оточуючими тканинами під час кросектомії або інших схожих процедур під час венектомії [3]. 3 категорія пацієнтів розглядалася більше як прогрес захворювання, ніж «чистий» рецидив, оскільки очевидно, що виникнення рефлюксу в непролікованих венозних басейнах не може бути наслідком будь-якої методики. При цьому слід враховувати, що оскільки сучасний флеболог має бути досвідченим фахівцем в ультразвуковій діагностиці, виникає питання якісної перевірки наявності рефлюксу в усіх венозних басейнах, та, відповідно, можливості тактичної помилки при доопераційному обстеженні пацієнта. 
Розподіл пацієнтів за методиками

\begin{tabular}{|l|c|c|c|}
\hline & $\begin{array}{c}\text { Група } \\
\text { «первинних» }\end{array}$ & $\begin{array}{c}\text { Група } \\
\text { «повторних» }\end{array}$ & Критерій Р \\
\hline ЕВЛК, всього: & 63 & 18 & 0,505 \\
\hline з них із кросектомісю & 24 & 0 & \\
\hline з них із «гемоглобіновим» лазером & 61 & 0 & 0,439 \\
\hline 3 них із «водним» лазером & 2 & 18 & 0,876 \\
\hline РЧО & 4 & 1 & 0,106 \\
\hline Час із моменту операції & $17,56 \pm 6,01$ & $18,41 \pm 3,65$ & \\
\hline
\end{tabular}

Щодо методик, за якими були проліковані пацієнти в нашій клініці - основною методикою була ЕВЛК з використанням діодного лазера 3 довжиною хвилі 1470 нм («водний») та радіальних 2-кільцевих та однокільцевих світловодів. Нами застосовувався лазерний апарат «Ліка Хірург» (Україна), світловоди виробництва Biolitec (ФРН), Tobrix (Нідерланди) та LGO (ФРН). 3 немедичних причин менше застосовувався апарат для РЧО
RFG-2 компанії «Medtronics» 3 електродом ClosureFast (все - США). Ультразвукове дослідження та інтра- та післяопераційний контроль здійснювались апаратом UGEO HM70A компанії «Samsung» (Південна Корея) 3 використанням лінійного датчика 7-12 МГц. Лазерні апарати з довжиною хвилі 940/960 нм («гемоглобінові») та торцеві світловоди не використовувались. Кросектомія за жодних обставин не проводилась.

Таблиця 4

Розподіл пацієнтів за ускладнюючими факторами

\begin{tabular}{|l|c|c|c|}
\hline & $\begin{array}{c}\text { Група } \\
\text { «первинних» }\end{array}$ & $\begin{array}{c}\text { Група } \\
\text { «повторних» }\end{array}$ & Критерій Р \\
\hline Варикотромбофлебіт & 5 & 4 & 0,804 \\
\hline Вроджена судинна мальформація & 12 & 2 & $>0,05$ \\
\hline Післятромбофлебітична хвороба & 5 & 1 & $>0,05$ \\
\hline $\begin{array}{l}\text { Анатомічні складнощі (діаметр вени > } 20 \text { мм, } \\
\text { звивистість вени) }\end{array}$ & - & 1 & - \\
\hline
\end{tabular}

3 метою виявлення можливих чинників, здатних вплинути на вірогідність рецидиву, дані пацієнтів були проаналізовані та виділені підгрупи пацієнтів 3 такими ускладнюючими факторами, як варикотромбофлебіт, вроджені судинні мальформації та післятромбофлебітична хвороба. Також, згідно з даними літератури [4], на результат лікування із застосуванням ЕТ методик може впливати діаметр вени $[4,5,6]$ та іï анатомічні особливості (звивистість тощо) $[4,7]$, але отримати такі дані для групи пацієнтів, оперованих не в нашій клініці («первинних»), було неможливо через відсутність подібних даних. Серед пацієнтів, оперованих в нашій клініці («вторинних»), лише в 1 пацієнта 3 діаметром ВПВ 26 мм в період 18 місяців виникла сегментарна реканалізація ділянки ВПВ, яка була усунена шляхом пінної склеротерапії (ПС).

Розбір особливостей вибору та застосування ЕТ методик та/або ПС не були метою даної роботи та дані питання будуть детально розглянуті в подальших роботах. Зважаючи на хірургічне спрямування роботи, залишити ці питання без короткого розгляду було б неправильно.

Пацієнтам з РФВХ проводились ЕВЛК та пінна склеротерапія (ПС), всі втручання відбувалися із застосуванням тумесцентної анестезії розчином Klein [9]. Використовувались радіальні слім (400 мкм) світловоди 2-кільцеві та 1-кільцеві (Biolitec (ФРН) та Tobrix (Нідерланди), відповідно). Проводи- лась безперервна ручна тракція світловоду на потужності 8-10 Вт, середній LEED складала 81 Дж/см. ПС проводилась піною $1 \%$ та 3\% етоксисклеролу під контролем ультразвуку, згідно з методикою Tessari [10], кількість сеансів варіювала від 2 до 5, в середньому 2,62. Після втручання призначались компресійні панчохи 2 класу призначались на 30 днів. Контрольні огляди з обов'язковим ультразвуковим контролем проводились на 1, 10, 30 та 90 день. Всі процедури виконувались в режимі стаціонару 1 дня.

Результати досліджень та їх обговорення. Аналіз даних пацієнтів з РФВХ дозволяє звернути увагу на декілька моментів:

$\checkmark$ значно меншу кількість неоангіогенезу ділянки співусть в нашій клініці можна пояснити відсутністю кросектомії в усіх випадках, можливий механізмвідсутність контакту внутрішньої стінки вени 3 оточуючими тканинами (що має місце при кросектомії);

$\checkmark$ переважне виявлення рефлюксу в нових зонах $\epsilon$, більшою мірою, ознакою прогресу захворювання, однак в деяких випадках можна говорити про вади діагностики на доопераційному етапі (невиявлення усіх шляхів рефлюксу на доопераційному ультразвуковому дослідженні);

$\checkmark$ низький рівень реканалізації стовбурів можна пояснити ефективністю відпрацьованої методики (поєднання радіального світловоду та «водного» лазера);

$\checkmark$ застосування кросектомії та «гемоглобінового» лазера та торцевого світловоду (одночасного 
застосування «гемоглобінового» лазера та радіального світловоду в нашій клініці не проводилось, та серед інших випадків виявлено не було) можливо підвищує ризик рецидиву;

$\checkmark$ проведення ЕТ методик пацієнтам з вродженими судинними мальформаціями та посттромбофлебітичною хворобою достовірно підвищує ризик рецидиву;

$\checkmark$ залежності ризику рецидиву від віку, статі чи ураженого венозного басейну виявлено не було;

$\checkmark$ середній час виявлення рецидиву - 19 місяців 3 моменту первинної операції, таким чином, в період між 12 та 24 місяцями після втручання слід особливо уважно проводити ультразвукові дослідження прооперованим пацієнтам.

У плані корекції РФВХ 38 (44,19\%) пацієнтам була проведена ЕВЛК, 28 (32,56\%) пацієнтам - ПС, $20(23,25 \%)$ пацієнтам була проведена ЕВЛК в поєднанні з ПС. Через 3, 6 та 12 місяців у 81 (94,19\%) пацієнта оброблені вени були оклюзовані, у 5 (5,81\%) пацієнтів був виявлений новий рефлюкс на пролікованих кінцівках. Серед пацієнтів 3 повторно виявленим рефлюксом були пацієнти 3 усіх 3 категорій. Однак якість життя поліпшилась в усіх випадках - середня кількість балів VCSS [10] до лікування складала 5,2; через 1 місяць VCSS складав 1,9; через 6 та 12 місяців кількість балів VCSS складала 1,3.

Висновки. Загалом, частота рецидивів після ЕT методик в нашій клініці відповідає загальносвітовим даним.

1. Застосування сучасних різновидів ЕТ методик здатне знизити ризик рецидиву, порівняно з попередніми різновидами методик.

2. Своєчасний та регулярний ультразвуковий контроль дозволяє виявити рецидив на ранніх стадіях та збільшити ефективність та мініінвазивність повторного втручання.

3. Повторне застосування мінінвазивних методик у пацієнтів з РФВХ $є$ технічно непростим завданням, але дає ефективність на рівні 94\%.

4. Застосування сучасних ЕТ методик в лікуванні РФВХ не тільки безпечне та ефективне, але дозволяє значно підвищити якість життя та косметичних ефект для пацієнта, що враховуючи стать та вік основного контингенту пацієнтів $\epsilon$ вкрай важливим.

Перспективи подалыших досліджень у даному напрямку. Навіть із впровадженням сучасних малотравматичних та високоефективних методик, проблема рецидиву варикозної хвороби досі не вирішена та потребує подальшого дослідження.

Інформація про конфлікт інтересів. Автори заявляють про відсутність конфлікту інтересів при виконанні наукового дослідження та підготовці даної статті.

Інформація про фінансування. Автори гарантують, що вони не отримували жодних винагород в будь-якій формі, здатних вплинути на результати роботи.

Особистий внесок кожного автора у виконання роботи:

Артеменко М.О. - розробка концепції і дизайну дослідження, збір матеріалу, статистична обробка даних, підготовка тексту;

Усенко О.Ю. -аналіз отриманих даних, редагування.

\section{Список використаної літератури}

1. O’Donnell TF, Balk EM, Dermody M, Tangney E, Iafrati MD. Recurrence of varicose veins after endovenous ablation of the great saphenous vein in randomized trials. J Vasc Surg: Venous and Lym Dis. 2016;4:97-105.

2. Bush RG, Bush P, Flanagan J, Fritz R, Gueldner T, Koziarski J, et al. Factors associated with recurrence of varicose veins after thermal ablation: results of the recurrent veins after thermal ablation study. The Scientific World Journal. 2014 Jan; Volume 2014. Article ID 505843, 7 p. Available from: https://www.hindawi.com/journals/tswj/2014/505843 DOI: 10.1155/2014/505843

3. Ostler AE, Holdstock JM, Harrison CC, et al. Strip-tract revascularization as a source of recurrent venous reflux following high saphenous tie and stripping: results at 5-8 years after surgery. Phlebology. 2015;30(8):569-72.

4. Van der Velden SK, et al. Predictors of recanalization of the great saphenous vein in randomized controlled trials 1 year after endovenous thermal ablation. European Journal of Vascular and Endovascular Surgery. 2016 Aug;52(2):234-41. Available from: https://www.ejves.com/article/S1078-5884(16)00059-9/fulltext DOI: 10.1016/j.ejvs.2016.01.021

5. Florescu C, Curry G, Buckenham T. Role of endovenous laser therapy in large and very large diameter great saphenous veins. ANZ J Surg. 2014 May;86(7-8):608-11. DOI: 10.1111/ans.12672

6. Starodubtsev V, Lukyanenko M, Karpenko A, Ignatenko P. Endovenous laser ablation in patients with wide diameter of the proximal segment of the great saphenous vein: Comparison of methods. Phlebology. 2015 Dec;30(10):700-5. DOI: 10.1177/0268355514555546.

7. Hao S, Cox S, Monahan TS, Flohr T, Sarkar R. A Defined protocol to resolving cannulation failure during endovenous ablation procedures. Annals of Vascular Surgery. 2017 Nov;45:324-9. DOI: 10.1016/j.avsg.2017.07.010.

8. Klein JA. The tumescent technique for liposuction surgery. Am J Cosmetic Surg. 1987;4:263-7.

9. Tessari L, Cavezzi A, Frullini A. Preliminary experience with a new sclerosing foam in the treatment of varicose veins. Dermatol Surg. 2001 Jan;27(1):58-60.

10. Vasquez MA, Rabe E, McLafferty RB, et al. Revision of the venous clinical severity score: Venous outcomes consensus statement: Special communication of the American Venous Forum Ad Hoc Outcomes Working Group. J Vasc Surg. 2010;52:1387-96.

Стаття надійшла до редакції: 23.08.2017 p. 